\title{
Prevalence of Obesity and Associated Risk Factors Among Adolescents in Ankara, Turkey
}

\author{
Sırma Ercan11, Yıldız Bilge Dallar1, Serdar Önen1, Özlem Engiz2 \\ ${ }^{1}$ Ankara Training and Research Hospital, Department of Pediatrics, Ankara, Turkey \\ ${ }^{2}$ Ankara Training and Research Hospital, Department of Pediatric Endocrinology, Ankara, Turkey
}

\begin{abstract}
Objective: The purpose of this study was to investigate the prevalence of and the risk factors associated with obesity among adolescents in Ankara, Turkey. Methods: The study was conducted in 26 schools in Ankara during the time period from September 2010 to March 2011. A total of 8848 adolescents aged 11-18 years were chosen using a population-based stratified cluster sampling method. Body mass index (BMI) of the participants was compared with the BMI references for Turkish children and adolescents to estimate the prevalence of overweight and obesity. A standardized questionnaire aiming to determine the sociodemographic characteristics, computer use, television (TV) watching, physical activity, and presence of obesity in the family was applied to the study group.

Results: The results showed that the overall prevalence of obesity among adolescents was $7.7 \%$ (8.4 \% for females and $7.0 \%$ for males). It was observed that BMl increased as computer use increased. A greater proportion of the overweight and obese adolescents watched TV and use computer for more than 2 hours/day as compared to their normal-weight counterparts. The normal-weight subjects were found to show a higher participation in regular physical activity. Obesity prevalence among the families of obese adolescents was $56.5 \%$.

Conclusions: The prevalence of adolescent obesity in Ankara, Turkey is lower as compared to many European countries and to the United States. Computer use, watching TV, physical activity and family factors are important risk factors for obesity.

Key words: Adolescents, obesity, prevalence, risk factors, Turkish
\end{abstract}

Conflict of interest: None declared

Received: 17.05 .2012

Accepted: 08.08.2012

\section{Introduction}

The prevalence of childhood obesity is on the rise around the world. At present, more than $30 \%$ of children and adolescents 2-19 years of age are classified as overweight or obese with a body mass index (BMI) higher than the 85th percentile of the Centers for Disease Control and Prevention growth charts for the year $2000(1,2)$. The World Health Organization (WHO) has designated obesity as a major public health problem in 1998 (3). Childhood and adolescence obesity is related to an increased adult morbidity and mortality by leading to a variety of conditions such as diabetes mellitus, hypertension, psychological disorders and social problems $(4,5,6)$. Therefore, it is important to monitor overweight and obesity in children and adolescents.

Several studies in Turkey have reported associations of obesity with different risk factors. Discigil et al (7) found high socio-economic status to be associated with childhood obesity. Oztora et al (8) observed that obesity correlated with television (TV) viewing and computer use for more than 4 hours. Akac et al (9) reported a statistically significant increase in the frequency of risk factors such as unhealthy eating habits, spending long hours watching TV, family history of obesity and high socio-economic status in obese children. Studies on obesity prevalence in certain age groups have been published in Turkey, but there is limited data regarding adolescents. Thus, this study aimed to identify the obesity prevalence and risk factors in an adolescent population in Ankara, Turkey.

\section{Address for Correspondence}

Özlem Engiz MD, Department of Pediatric Endocrinology, Ankara Training and Research Hospital, Ankara, Turkey

Phone: +90 3125953278 E-mail: oengiz@yahoo.com

This study was accepted as an electronic poster at ESPE 2012, Leipzig, Germany

(๑) Journal of Clinical Research in Pediatric Endocrinology, Published by Galenos Publishing. 


\section{Methods}

The anthropometric survey was conducted in Ankara during the time period from September 2010 to March 2011. A multistage random cluster sampling technique was used. A total of 8848 students were randomly selected from 26 schools in 6 districts of Ankara. A standardized questionnaire was distributed to these students. Gender, age, physical activity, computer use, TV viewing, as well as weight status of parents and family history of obesity were included in the questionnaire. Regular physical activity was defined as activity performed at least 3 days a week, each episode lasting at least 60 minutes.

The body weight and height of the students were measured by the same person. Weight was measured using a portable electronic scale with the subject wearing light clothes and no shoes. Height was measured using a stadiometer with the subject's shoes off, feet together, and head in the horizontal plane. The BMI was calculated using the formula: body weight $(\mathrm{kg}) /$ height squared $\left(\mathrm{m}^{2}\right)$. The degree of obesity was defined using the reference data on Turkish children (10).

The data were analyzed using the Statistical Package for the Social Sciences (SPSS v. 11.5, Chicago, IL, United States). Continuous variables with normal distribution were expressed as mean \pm standard deviation (SD) and compared using the analysis of variance (ANOVA) test. Categorical variables were expressed as frequencies and compared between the groups with Pearson's chi-square test or Fisher's exact test. A pvalue of less than 0.05 was considered statistically significant.

This study was approved by the Ethics Committee of the Ankara Training and Research Hospital.

\section{Results}

The sample representing the age groups between 11 and 18 years consisted of 8848 subjects [ 4408 girls $(49.8 \%)$ and 4440 boys $(50.2 \%)]$. The mean age was $14.2 \pm 2.2$ years (range 11-18). Of the 8848 adolescents, $52.4 \%$ were attending primary school (11-14 years of age) and $47.6 \%$ were attending secondary school (15-18 years of age), thus, the subjects were divided into two groups (11-14 and 15-18 age groups) to evaluate the effect of age on risk factors of obesity. The prevalence of short stature was $1.5 \%$. The overall prevalence of obesity in this representative sample of adolescents in Ankara was $7.7 \%$. The prevalence rates of obesity in girls and boys were $8.4 \%$ and $7 \%$, respectively; the difference was statistically significant $(p<0.001)$. The prevalence rates of obesity in the 11-14 age group and in the $15-18$ age group were $5.9 \%$ and $9.6 \%$, respectively; this difference was also statistically significant $(p<0.001)$ (Table 1).
The overall prevalence of computer use was $80 \%$, being $72.3 \%$ in girls and $87.3 \%$ in boys; the difference was statistically significant $(p<0.001)$. The prevalence rates of computer use in the 11-14 age group and in the 15-18 age group were $74.5 \%$ and $85.7 \%$, respectively; this difference was also statistically significant $(p<0.001)$. The adolescents in the 15-18 age group used the computer for a period longer than 2 hours/day as compared to the adolescents in the 1114 age group $(p<0.001)$.

This study showed that BMI increased as computer use (hours/day) increased. The overweight and obese adolescents used the computer for periods longer than 2 hours/day compared to their normal-weight counterparts $(p<0.001)$ (Table 2).

The prevalence of TV viewing for $\geq 2$ hours/day was $52.4 \%$ among the adolescents, while $4.5 \%$ did not watch TV. A greater proportion of the girls were TV viewers as compared to the boys $(p<0.001)$. A greater proportion of adolescents in the 15-18 age group watched TV for 2 hours/day or for longer periods as compared to the adolescents in the 11-14 age group. Obese and overweight adolescents watched TV for more than 2 hours/day compared to normal-weight subjects $(p<0.001)$ (Table 2).

Physical activity was performed regularly by $30.7 \%$ of adolescents and irregularly - by $15.6 \%$. More than half (53.7\%) of the adolescents were not involved in any physical activity. The prevalence rates of regular physical activity in girls and boys were $19.5 \%$ and $41.8 \%$, respectively; the difference was statistically significant $(p<0.001)$. The prevalence rates of regular physical activity among adolescents in the 11-14 age group and in the 15-18 age group were $23.5 \%$ and $38.8 \%$, respectively; the difference was also statistically significant $(p<0.001)$. The normal-weight subjects were engaged in more regular physical activity compared to their overweight/obese counterparts $(p<0.05)$ (Table 2$)$.

The overall prevalence of familial obesity (obesity in firstdegree family members - one or both parents, siblings) was $22.8 \%$ in this study. The prevalence of familial obesity was found to be as high as $56.5 \%$ among the obese adolescents,

Table 1. The distribution of obesity with respect to age and sex

\begin{tabular}{lllll}
\hline Variables & $\begin{array}{l}\text { Normal weight } \\
\mathbf{n}(\%)\end{array}$ & $\begin{array}{l}\text { Overweight } \\
\mathbf{n}(\%)\end{array}$ & $\begin{array}{l}\text { Obese } \\
\mathbf{n}(\%)\end{array}$ & $\mathbf{p}$ \\
\hline Age & & & & $<0.001$ \\
11-14 years & $4036(87)$ & $329(7.1)$ & $273(5.9)$ & \\
15-18 years & $3397(80.7)$ & $408(9.7)$ & $405(9.6)$ & \\
Sex & & & & $<0.001$ \\
Girls & $3587(81.1)$ & $466(10.6)$ & $369(8.4)$ & \\
Boys & $3860(86.9)$ & $271(6.1)$ & $309(7)$ & \\
\hline
\end{tabular}


significantly higher than among the normal-weight and overweight subjects $(p<0.001)$ (Table 2). Maternal obesity prevalence rate was $29.7 \%$ while paternal obesity prevalence rate was $27.7 \%$ in the study population. The obesity prevalence rate in both parents and siblings was $26.3 \%$ and $12.1 \%$ respectively.

\section{Discussion}

Obesity is prevalent in the developed world. Data from the National Health and Nutrition Examination Survey (NHANES) 1988-1994 illustrate an obesity prevalence rate of $13.7 \%$ in the $6-11$ age group and $11.5 \%$ in the $12-17$ age group in the United States (11). Also, the NHANES 2003-2006 has reported an obesity prevalence rate of $16.3 \%$ in the $2-19$ age group (12). In Europe, the highest obesity prevalence rates in school-aged children have been estimated in Spain and Portugal, while the lowest rates have been reported from Slovakia, France, Switzerland, and Iceland (13).

Various reports in Turkish children and adolescents indicate that the prevalence of overweight and obesity may change by regions, however, the overall figures are lower as compared to many European countries and to the US $(14,15,16,17,18)$. In our study, the overweight prevalence rate was $8.3 \%(7.1 \%$ in the $11-14$ age group and $9.7 \%$ in the $15-$ 18 age group) and the obesity prevalence rate was $7.7 \%$ $(5.9 \%$ in the $11-14$ age group and $9.6 \%$ in the $15-18$ age group). These results were comparable to other Turkish studies but lower than those reported for European countries and the United States.

Obesity and sedentary life style are closely related. In this study, $20.9 \%$ of the adolescents reported using computer for more than 2 hours/day. Similar to other published studies, boys spent more time than girls using computer $(19,20)$. Computer use was more prevalent in obese and overweight children. In this study, nearly half (52.4\%) of the adolescents reported watching 2 or more hours of TV per day. The proportion of obese and overweight adolescents watching TV for more than 2 hours/day was higher as compared to normalweight ones. A study by Ozmert et al (21) reported similar results. Children with a BMI z-score $>2$ SD watched TV for longer periods than those with BMI z-scores < -2 SD.

Decreased physical activity is a serious risk factor for obesity $(22,23)$. In our study, more than $50 \%$ of the adolescents did not participate in any physical activity; $30 \%$ of the adolescents reported performing some regular activity. Boys declared more regular activity than girls. These results are similar to data published by Agazzi et al (20). Adolescents with normal body

Table 2. Relationships between obesity and computer use, television (TV) watching, physical activity and family history of obesity

\begin{tabular}{|c|c|c|c|c|}
\hline Variables & $\begin{array}{l}\text { Normal weight } \\
(n=7433)\end{array}$ & $\begin{array}{l}\text { Overweight } \\
(n=737)\end{array}$ & $\begin{array}{l}\text { Obese } \\
(n=678)\end{array}$ & p \\
\hline Computer use & 5781 (77.8) & $631(85.6)$ & $652(96.2)$ & $<0.001$ \\
\hline \multicolumn{5}{|l|}{ Computer use time } \\
\hline 1 hour/day & $3244(56.1)$ & $238(37.7)$ & $167(25.6)$ & \\
\hline 2 hours/day & $1510(26.1)$ & $128(20.3)$ & $300(46.0)$ & \\
\hline$>2$ hours/day & 1027 (17.8) & $265(42.0)$ & $185(28.4)$ & $<0.001$ \\
\hline \multicolumn{5}{|l|}{ TV watching } \\
\hline Do not watch & $368(5.0)$ & $15(2.0)$ & $13(1.9)$ & \\
\hline 1 hour/day & 3363 (45.2) & $260(35.3)$ & $191(28.2)$ & \\
\hline 2 hours/day & 2431 (32.7) & $249(33.8)$ & $320(47.2)$ & \\
\hline$>2$ hours/day & $1271(17.1)$ & $213(28.9)$ & $154(22.7)$ & $<0.001$ \\
\hline \multicolumn{5}{|l|}{ Physical activity } \\
\hline No activity & $3944(53.1)$ & $408(55.4)$ & $396(58.4)$ & \\
\hline Irregular & $1161(15.6)$ & $119(16.1)$ & $100(14.8)$ & \\
\hline Regular & $2328(31.3)$ & $210(28.5)$ & $182(26.8)$ & 0.048 \\
\hline Family history of obesity & $1415(19.0)$ & $216(29.3)$ & $383(56.5)$ & $<0.001$ \\
\hline
\end{tabular}


weight reported more regular physical activity compared to their overweight and obese counterparts.

Having overweight parents has been shown to be a strong determinant of childhood obesity (24). A study by Burke et al (25) demonstrated the associations between child BMI and parental BMI. In this study, obesity in fathers was associated with a four-fold increase in the risk of obesity at the age of 18 years in both sons and daughters with an independent eightfold increase in the risk for daughters if mothers were obese. In our study, $56 \%$ of the obese adolescents had an obese family member. The mean BMI of the adolescents increased as the parental BMI increased. In another study including 3306 children aged 5-7 years and their parents, the BMI of the children was found to be significantly correlated with the parental BMI. The children's BMI showed closer associations with maternal than with paternal BMI (26). In the present study, maternal obesity rate was highest in the study population. This may be due to mothers having a greater influence on their children's nutrition in our society. Further prospective and comprehensive studies are needed on this topic.

In conclusion, the obesity prevalence among Turkish adolescents in the city of Ankara is relatively low as compared to many European countries and to the US. Computer use and TV viewing as well as physical activity and family factors are important risk factors for obesity in Turkish adolescents. Healthy nutrition and regular physical activity should be promoted to prevent obesity.

\section{References}

1. Ogden $C L$, Carroll MD, Curtin LR, McDowell MA, Tabak CJ, Flegal KM. Prevalence of overweight and obesity in the United States, 1999-2004. JAMA 2006;295:1549-1555.

2. Ogden $C L$, Carroll MD, Flegal KM. High body mass index for age among US children and adolescents, 2003-2006. JAMA 2008;299:2401-2405.

3. Obesity: preventing and managing the global epidemic. Report of a WHO consultation. World Health Organ Tech Rep Ser 2000:894:1-253.

4. Pinhas-Hamiel O, Dolan LM, Daniels SR, Standiford D, Khoury PR, Zeitler P. Increased incidence of non-insulindependent diabetes mellitus among adolescents. J Pediatr 1996;128:608-615.

5. Sorof J, Daniels S. Obesity hypertension in children: a problem of epidemic proportions. Hypertension 2002;40:441-447.

6. Strauss RS. Childhood obesity and self-esteem. Pediatrics 2000;105:15.

7. Discigil G, Tekin N, Soylemez A. Obesity in Turkish children and adolescents: prevalence and non-nutritional correlates in an urban sample. Child Care Health Dev 2009;35:153-158.

8. Oztora S, Hatipoglu S, Barutcugil MH, Salihoglu B, Yildirim R, Sevketcioglu E. Illköğretim çağındaki çocuklarda obezite prevalansının belirlenmesi ve risk faktörlerinin araştırılması. Bakırköy Tıp Dergisi 2006;2:11-14.

9. Akac H, Babaoglu K, Hatun S, Aydogan M, Turker G, Gokalp AS. Kocaeli bölgesindeki okul çağı çocuklarında obezite ve risk faktörleri. Çocuk Dergisi 2002;2:29-32.
10. Bundak R, Furman A, Gunoz H, Darendeliler F, Bas F, Neyzi O. Body mass index references for Turkish children. Acta Paediatr 2006;95:194-198.

11. Troiano RP, Flegal KM, Kucmarski RJ, Campbell SM, Johnson $\mathrm{CL}$. Overweight prevalence and trends for children and adolescents. The National Health and Nutrition Examination Surveys, 1963 to 1991. Arch Pediatr Adolesc Med 1995;149:1085-1091.

12. Molarius A, Seidel JC, Sans S, Toumilehto J, Kuulasmaa K. Varying sensitivity of waist action levels to identify subjects with overweight or obesity in 19 populations of the WHO MONICA Project. J Clin Epidemiol 1999;52:1213-1224.

13. Branca F, Nikogosian $H$, Lobstein T. The Challenge of obesity in the WHO European Region and the strategies for response. WHO, Denmark, 2007.

14. Krassas GE, Tsametis C, Baleki V, Constantinidis T, Unluhizarci K, Kurtoglu S, Kelestimur F; Balkan Group for the Study of Obesity. Prevalence of overweight and obesity among children and adolescents in Thessaloniki, Greece and Kayseri-Turkey. Pediatr Endocrinol Rev 2004;1:460-464.

15. Suzek H, Ari Z, Uyanik BK. Muğla'da yaşayan 6-15 yaş okul çocuklarında kilo fazlalığı ve obezite prevalansı. Türk Biyokimya Dergisi 2005;30:290-295.

16. Cinaz P, Camurdan O, Maral I, et al. 6-16 yaş arası 12589 çocukta obezite sıklığı ve risk faktörleri. Poster sunumu, VIII. Ulusal Pediatrik Endokrinoloji Kongresi, Erzurum, 2003.

17. Arı Yuca S, Yilmaz C, Cesur Y, Dogan M, Kaya A, Basaranoglu $M$. Prevalence of overweight and obesity in children and adolescents in eastern Turkey. J Clin Res Pediatr Endocrinol 2010;2:159-163.

18. Oner N, Vatansever U, Sari A, Ekuklu E, Guzel A, Karasalihoglu S, Boris NW. Prevalence of underweight, overweight and obesity in Turkish adolescents. Swiss Med Wkly 2004;134:529-533.

19. Wake M, Hesketh K, Waters E. Television, computer use and body mass index in Australian primary school children. $J$ Paediatr Child Health 2003;39:130-134.

20. Agazzi H, Armstrong K, Bradley-Klug KL. BMI and physical activity among at-risk sixth- and ninth-grade students, Hillsborough County, Florida, 2005-2006. Prev Chronic Dis 2010;7:48. Epub 2010 Apr 15

21. Ozmert EN, Ozdemir R, Pektas A, Uckardes Y, Yurdakok K. Effect of activity and television viewing on BMI z-score in early adolescents in Turkey. World J Pediatr 2011;7:37-40. Epub 2010 Dec 30

22. Pérez A, Hoelscher DM, Springer AE, Brown HS, Barroso CS, Kelder SH, Castrucci BC. Physical activity, watching television, and the risk of obesity in students, Texas, 20042005. Prev Chronic Dis 2011;8:61. Epub 2011 Apr 15

23. Laurson KR, Eisenmann JC, Welk GJ, Wickel EE, Gentile DA, Walsh DA. Combined influence of physical activity and screen time recommendations on childhood overweight. J Pediatr 2008;153:209-214. Epub 2008 Apr 16

24. Lake JK, Power C, Cole TJ. Child to adult body mass index in the 1958 British birth cohort: associations with parental obesity. Arch Dis Child 1997;77:376-381.

25. Burke V, Beilin LJ, Dunbar D. Family lifestyle and parental body mass index as predictors of body mass index in Australian children: a longitudinal study. Int J Obes Relat Metab Disord 2001;25:147-157.

26. Danielzik S, Langnäse K, Mast M, Spethmann C, Müller MJ. Impact of parental BMI on the manifestation of overweight 5-7 year old children. Eur J Nutr 2002;41:132-138. 